\title{
HPLC-DAD finger printing, antioxidant, cholinesterase, and a-glucosidase inhibitory potentials of a novel plant Olax nana
}

Muhammad Ovais ${ }^{1,2}$, Muhammad Ayaz ${ }^{3^{*}}$ (D) Ali Talha Khalil ${ }^{4}$, Sayed Afzal Shah ${ }^{5}$, Muhammad Saeed Jan ${ }^{3}$, Abida Raza ${ }^{6}$, Muhammad Shahid ${ }^{7}$ and Zabta Khan Shinwari ${ }^{1,8}$

\begin{abstract}
Background: The medicinal importance of a novel plant Olax nana Wall. ex Benth. (family: Olacaceae) was revealed for the first time via HPLC-DAD finger printing, qualitative phytochemical analysis, antioxidant, cholinesterase, and a-glucosidase inhibitory assays.

Methods: The crude methanolic extract of $\mathrm{O}$. nana $(\mathrm{ON}-\mathrm{Cr})$ was subjected to qualitative phytochemical analysis and HPLC-DAD finger printing. The antioxidant potential of ON-Cr was assessed via 1,1-diphenyl,2-picrylhydrazyl (DPPH), 2,2-azinobis[3-ethylbenzthiazoline]-6-sulfonic acid (ABTS) and hydrogen peroxide $\left(\mathrm{H}_{2} \mathrm{O}_{2}\right)$ free radical scavenging assays. Furthermore, acetylcholinesterase (AChE) \& butyrylcholinesterase (BChE) inhibitory activities were performed using Ellman's assay, while a- glucosidase inhibitory assay was carried out using a standard protocol.

Results: The qualitative phytochemical analysis of $\mathrm{ON}-\mathrm{Cr}$ revealed the presence of secondary metabolites like alkaloids, flavonoids, tannins, sterols, saponins and terpenoids. The HPLC-DAD finger printing revealed the presence of 40 potential compounds in $\mathrm{ON}-\mathrm{Cr}$. Considerable anti-radical activities was revealed by $\mathrm{ON}-\mathrm{Cr}$ in the DPPH, ABTS and $\mathrm{H}_{2} \mathrm{O}_{2}$ free radical scavenging assays with $I_{50}$ values of $71.46,72.55$ and $92.33 \mu \mathrm{g} / \mathrm{mL}$, respectively. Furthermore, ON-Cr showed potent $A C h E$ and $B C h E$ inhibitory potentials as indicated by their $\mathrm{IC}_{50}$ values of 33.2 and $55.36 \mu \mathrm{g} / \mathrm{mL}$, respectively. In the a-glucosidase inhibition assay, ON-Cr exhibited moderate inhibitory propensity with an $\mathrm{IC}_{50}$ value of 639 . $89 \mu \mathrm{g} / \mathrm{mL}$.

Conclusions: This study investigated Olax nana for the first time for detailed qualitative phytochemical tests, HPLC-DAD finger printing analysis, antioxidant, anticholinesterase and a-glucosidase inhibition assays. The antioxidant and cholinesterase inhibitory results were considerable and can provide scientific basis for further studies on the neuroprotective and anti-Alzheimer's potentials of this plant. ON-Cr may further be subjected to fractionation and polarity guided fractionation to narrow down the search for isolation of bioactive compounds.
\end{abstract}

Keywords: Olax nana, Phytochemical analysis, HPLC-dad, Acetylcholinesterase (AChE), Butyrylcholinesterase (BChE), DPPH, $\mathrm{H}_{2} \mathrm{O}_{2}$, ABTS, a-glucosidase inhibitory assays

\footnotetext{
* Correspondence: ayazuop@gmail.com

${ }^{3}$ Department of Pharmacy, University of Malakand, Khyber Pakhtunkhwa

(KPK), Chakdara 18000, Pakistan

Full list of author information is available at the end of the article
}

(c) The Author(s). 2018 Open Access This article is distributed under the terms of the Creative Commons Attribution 4.0 International License (http://creativecommons.org/licenses/by/4.0/, which permits unrestricted use, distribution, and reproduction in any medium, provided you give appropriate credit to the original author(s) and the source, provide a link to the Creative Commons license, and indicate if changes were made. The Creative Commons Public Domain Dedication waiver (http://creativecommons.org/publicdomain/zero/1.0/) applies to the data made available in this article, unless otherwise stated. 


\section{Background}

Humans have used medicinal plants as a remedy against various diseases since time immemorial [1]. The presence of various bioactive components in different parts of plants make them an important resource for the treatment of various diseases. Furthermore, the side effects associated with some of the synthetic medications and antibiotic resistance demands intermittent research for alternative solutions $[2,3]$. In addition, to their direct therapeutic use, medicinal plants have been explored to fabricate various nanoscaled materials for potential biomedical applications [4-9]. Natural products based alternative therapies are still practiced in many countries and globally approximately $80 \%$ of population trust on herbal medicine as a primary source of therapeutic remedies [10]. In the last decade, a revival has been observed in the use of medicinal plants and herbal medicines. It is forecasted that the global market for herbal medicine will expand over time due to the preference of consumers for natural medicines [11]. Moreover, by the year 2017, the worldwide herbal supplements and remedies market is forecasted to reach $\$ 107$ billion [12].

The genus Olax belongs to family Olacaceae [13], which contains several medicinally important plants [14]. Among the Olacaceae species, Olax subscorpioidea, is reported to have applications in the management of analgesic, cancer, yellow fever, inflammatory diseases, mental illness, Alzheimer's disease, parasitic, microbial infections and hepatological disorders [14-23]. Olax scandens revealed the presence of highly useful phytochemicals like sitosterol, octacosanol, oleanolic acid, aleanolic acid and $\beta$-sitosterol [24]. Several studies confirmed the pharmacological importance of $O$. scandens in bacterial infections, cancer, headache and psoriasis [25-27]. Moreover, the aqueous extract of Olax zeylanica was found effective against skin diseases and exhibits photoprotective activity, whereas, Olax dissitiflora have mosquito repellent properties [28, 29]. The phytochemical analysis of Olax mannii Oliv revealed the presence of three new flavonoid triglycosides including kaempferol 3-O-[ $\beta$-D-glucopyranosyl-(1-2)- $\alpha$-L-arabinofuranoside]-7-O- $\alpha$-L-rhamnopyranoside, kaempferol 3-O-[ $\beta$-D-arabinopyranosyl-(1-4)- $\alpha$-L-rhamnopyranoside]7-O- $\alpha$-L-rhamnopyranoside, kaempferol 3-O-[ $\alpha$-D-apiofuranosyl-(1-2)- $\alpha$-L-arabinofuranoside]-7-O- $\alpha$-L-rhamnopyra noside, kaempferol 3-O- $\alpha$-L-rhamnopyranoside and fourteen already known flavonoids glycosides which are potential anti-cancer and anti-inflammatory agents [30].

Free radicals are implicated in the progression of several disorders like, cancer, ischemic heart diseases, neurodegenerative diseases, diabetics, reperfusion injuries, arthritis and atherosclerosis [31]. Free radicals from various sources like toxins, environmental pollutants and deep fried foods cause abnormal genes expression and proteins synthesis which initiate degenerative reactions in the body [32]. In the living systems, generation of free radicals occur via oxidation process, which are nullified to non-radical forms in the human body by natural antioxidants. Hence, apart from our own immune system which acts against these free radicals, natural antioxidants are of prime importance to counter them [33]. Synthetic antioxidants like tertiary butyl hydro quinone, propyl gallate, butylated hydroxytoluene and butylated hydroxyanisole are associated with adverse effects to human health. Hence, natural antioxidants form plants are found to be best alternative for synthetic antioxidants [33]. Many published studies validate the potential antioxidant potential of medicinal plants crude extracts and of isolated pure compounds [34, 35]. Flavonoids and phenolics are considered as potent antioxidants due to the presence of hydroxyl groups and conjugated ring structures, which via hydrogenation or complexation scavenge free radicals [36].

Alzheimer's disease (AD) is a common neurodegenerative disorder characterized by behavioral turbulence, cognitive dysfunction and imperfection in the routine activities. Its prevalence is high among individuals of age above sixty years [37]. Currently only five drugs have been approved for clinical use, among which four are cholinesterase inhibitors [38]. The cholinesterase's including acetyl cholinesterase (AChE) and butyrycholinesterase (BChE) catalytically metabolize acetylcholine (ACh) in the synaptic cleft [39]. Acetylcholine is an important neurotransmitter involved in the transmission of impulses across the synapse and is vital in the acquisition and storage of memory. The level of ACh has been found to be depleted in $\mathrm{AD}$ [40]. Among the options is the use of inhibitors of $\mathrm{AChE}$ and $\mathrm{BChE}$ which will restore the activity of $\mathrm{ACh}$ at the synapse. Among the clinically approved cholinesterase inhibitors, two are from natural products including galantamine and rivastigmine. Consequently, natural products are under consideration for the development of more useful cholinesterase inhibitors [41].

Diabetes is a major health problem which is associated with high blood glucose level in the body. The $\alpha$-glucosidase enzyme plays a key role in the control of glucose level inside the body as they are related to postprandial glucose excursion in a person suffering from diabetes [42, 43]. $\alpha$ Glucosidase breakdown carbohydrates into glucose and therefore increases the glucose level inside the body. Henceforth, $\alpha$-glucosidase inhibition (AGI's) is considered as a popular strategy for controlling post prandial glucose level. Many plants have been researched for natural AGI's like Punica granatum, Pine bark and Andrographis paniculata [44].

To the best of our information there is no single report on the phytochemical investigation and pharmacogonostic features (anticholinesterase, antioxidant and $\alpha$-glucosidase inhibitory potential) of $O$. nana. Therefore, the present research was undertaken to investigate and scientifically 
validate the use of $O$. nana aqueous methanolic extract against ailments such as diabetes and neurogenerative diseases.

\section{Methods}

\section{Plant collection and extraction}

O. nana whole plant was collected from Swat district of Khyber Pakhtunkhwa, Pakistan in June 2016 (Fig. 1). The plant was authenticated by botanical taxonomist Syed Afzal Shah (PhD Candidate) and Dr. Mushtaq (plant taxonomist) at the Department of Plant Sciences, Quaid-i-Azam University, Islamabad, Pakistan. A sample was deposited at MOSEAL Laboratory, Department of Biotechnology, Quaid-i-Azam University with a voucher number MOSEAL-344. The plant was gently rinsed with running distilled water followed by shade drying for 10 days. Subsequently, the dried leaves were grinded via cutter mill to obtain a fine powdered material that weigh $\sim 1 \mathrm{~kg}$. In a $1 \mathrm{~L}$ of $70 \%$ aqueous methanol, $300 \mathrm{~g}$ of the powdered plant was soaked for 5 days in a shaking incubator $\left(37^{\circ} \mathrm{C}\right)$, with frequent sonication (60 $\mathrm{Hz}$ for 5 mints every day) using a sonicator (Elmasonic E $60 \mathrm{H}$ - Cousins UK). The extraction step was repeated thrice, with the addition of extract to the original one and filtered via muslin cloth, ultimately followed by final filtration through Whatman qualitative filter paper, Grade 1. Furthermore, in a rotary evaporator (EYELA N-1300S-W 115 V, Tokyo Rikakikai Co., LTD), the crude methanolic extract $(\mathrm{ON}-\mathrm{Cr})$ was concentrated, ultimately resulted in a $\sim 20 \mathrm{~g}$ mass of dark brownish semisolid [45].

\section{Chemical and drugs}

For antioxidant assays, 1,1-diphenyl, 2-picrylhydrazyl (DPPH) and 2, 2-azinobis [3-ethylbenzthiazoline]-6-sulfonic acid (ABTS) (CAS 1898-66-4 and CAS 30931-67-0 Sigma Aldrich, USA, $\mathrm{K}_{2} \mathrm{~S}_{2} \mathrm{O}_{4}$ (Riedel-de Haen Germany) were purchased from authorized dealers in Pakistan.
For anticholinesterase and $\alpha$-glucosidase studies, AChE from Electric eel (type-VI-S, CAS 9000-81-1), BChE from equine serum lyophilized (CAS 9001-08-5) and $\alpha$ glucosidase from Saccharomyces cerevisiae CAS 9001-427 were purchased from Sigma-Aldrich GmbH USA. The substrates including acetylthiocholine iodide (CAS186615-5), butyrylthiocholine iodide (CAS 2494-56-6), p-nitrophenyl- $\alpha$-D-glucopyranoside glucopyranoside (CAS 2492-87-7), were purchased from Sigma-Aldrich UK and Sigma-Aldrich, Switzerland, respectively. Similarly, the indicator substance, 5,5-dithio-bis-nitrobenzoic acid (DTNB) CAS 69-78-3 was purchased from Sigma-Aldrich Germany. The standard drugs, galantamine hydrobromide, Lycoris Sp. (CAS 1953-04-4), acarbose alfa aesar (CAS 56180-94-0) and ascorbic acid were purchased from Sigma-Aldrich France. The buffer system including $\left(\mathrm{K}_{2} \mathrm{HPO}_{4}\right),\left(\mathrm{KH} 2 \mathrm{PO}_{4}\right), \mathrm{KOH}$ and solvents used were of extra pure quality.

\section{Phytochemical analysis Preliminary phytochemical tests}

For the identification of various secondary metabolites including alkaloids, flavonoids, glycosides, saponins, sterols, tannins, terpenoids and anthraquinones, qualitative phytochemical tests were performed following standard protocols as reported previously [46].

\section{Determination of alkaloids (Dragendorff's method)}

The crude methanolic extract $(0.2 \mathrm{~g})$ was taken in a conical flask and sulphuric acid (2\%) was added. The conical flask was placed on a hot water bath for 2 min and then cooled. The sample was then filtered and treated with Dragendorff's reagent in a test tube. The orange red color precipitate in the test tube showed the presence of alkaloids.

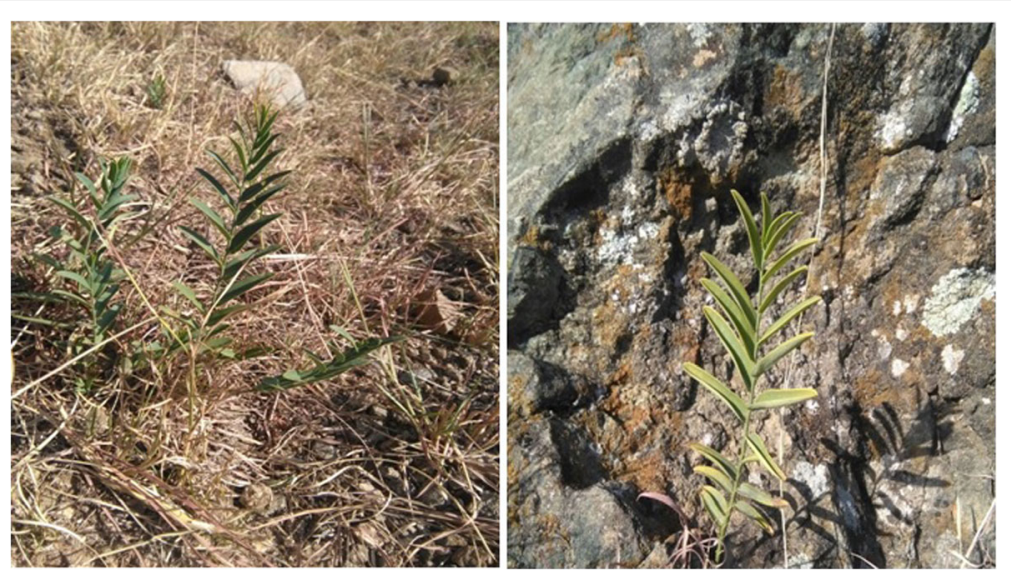

Fig. 1 Snapshot of Olax nana plant at collection point (Location: Swat district of Khyber Pakhtunkhwa, Pakistan) 


\section{Test for flavonoids}

In a conical flask, dried powdered material was boiled with $10 \mathrm{~mL}$ of distilled water in a hot water bath for about $5 \mathrm{~min}$ and then filtered. After cooling the mixture, few drops of sodium hydroxide solution (20\%) was added to $1 \mathrm{~mL}$ of the cooled filtrate, which changed the color to yellow. Further addition of $2 \% \mathrm{HCl}$ changed the yellow color of mixture to colorless.

\section{Test for tannins}

To $2 \mathrm{~g}$ of sample, $20 \mathrm{~mL}$ of distilled water was added and boiled for about $5 \mathrm{~min}$ in a hot water bath. The boiled solution was filtered immediately and then cooled at room temperature. A $1 \mathrm{~mL}$ of filtrate was taken and added to $5 \mathrm{~mL}$ of distilled water. Then $10 \%$ of ferric chloride (2-3 drops) was added. The appearance of bluish-black precipitate or brownish-green color showed the presence of tannins.

\section{Test for anthraquinones}

A 2 g powdered plant sample was taken and macerated with ether. The solution was shaken and checked, the appearance of red, violet or pink color in the aqueous layer indicated the presence of anthraquinone.

\section{Test for Saponins}

The powdered plant material $(0.2 \mathrm{~g})$ along with $10 \mathrm{~mL}$ of distilled water was taken in a conical flask and boiled in a water bath for about $10 \mathrm{~min}$. The hot mixture was then filtered and allowed to cool. A $1 \mathrm{~mL}$ of filtrate along with $2 \mathrm{~mL}$ of distilled water was taken in a test tube and vigorously shaken for $2 \mathrm{~min}$. The formation of froth indicates the presence of saponins in the filtrate. Olive oil was then added drop wise to the froth and after shaking the mixture, a formation of emulsion was observed.

\section{Test for glycosides}

To a test tube containing a mixture of concentrated sulphuric acid $(1 \mathrm{~mL})$, aqueous plant extract $(5 \mathrm{~mL})$ and glacial acetic acid $(2 \mathrm{~mL})$, a drop of ferric chloride was added. The concentrated sulphuric acid remained beneath the mixture. The appearance of brown ring indicated the presence of cardiac glycoside.

\section{Test for Terpenoids (Salkowski's test)}

For the identification of Terpenoids, powdered plant material was dissolved in $5 \mathrm{~mL}$ of aqueous solution and boiled in a water bath and then allowed to cool. The solution is filtered, and $2 \mathrm{~mL}$ of chloroform was added to the filtrate in a test tube; followed by addition of $3 \mathrm{~mL}$ of concentrated sulphuric acid. The appearance of reddish brown interface indicated the presence of terpenoid in the sample.
High performance liquid chromatography-Diaode Array detection (HPLC-DAD) analysis

\section{Samples preparation}

The extract sample for HPLC was prepared by mixing $20 \mathrm{~mL}$ of hydromethanolic mixture $(1: 1 \mathrm{v} / \mathrm{v})$ with $1 \mathrm{~g}$ of $\mathrm{ON}-\mathrm{Cr}$. The resultant mixture was heated in a water bath at $70{ }^{\circ} \mathrm{C}$ for $1 \mathrm{~h}$ with subsequent cooling. Thereafter, the sample was centrifuged for $10 \mathrm{~min}$ at $4000 \mathrm{rpm}$. Finally, $2 \mathrm{~mL}$ of test sample was filtered through a Whatman filter paper into HPLC vials.

\section{HPLC-DAD procedure}

An Agilent 1260 infinity high-performance liquid chromatography (HPLC) system provided with ultraviolet array detector (UVAD), quaternary pump, auto-sampler and degasser was used. Separation was done using an Agilent Zorbax Eclipse XDB-C18 column. A gradient system consisting of solvent B (methanol: acetic acid; deionized water, 100: 20: 180, $v / \mathrm{v}$ ) and solvent $C$ (methanol: acetic acid: deionized water, 900: 20: 80, v/v) was used. The gradient program was started with $100 \% \mathrm{~B}$ at $0 \mathrm{~min}, 85 \% \mathrm{~B}$ at $5 \mathrm{~min}, 50 \% \mathrm{~B}$ at $20 \mathrm{~min}, 30 \% \mathrm{~B}$ at $25 \mathrm{~min}$, and $100 \% \mathrm{C}$ for $30-40 \mathrm{~min}$ [47]. Using this sequence, elution occurred after $25 \mathrm{~min}$. For analysis of compounds, the ultraviolet array detector (UVAD) was set at $280 \mathrm{~nm}$ and the spectra were recorded from 190 to $500 \mathrm{~nm}$. Two standard compounds, rutin and pyrogallol were detected in the HPLC analysis.

\section{Antioxidant assays}

1,1-diphenyl, 2-picrylhydrazyl (DPPH) free radical scavenging assay $\mathrm{ON}-\mathrm{Cr}$ was tested for $\mathrm{DPPH}$ free radical scavenging assay as previously reported [35, 48]. Briefly, $0.004 \%$ DPPH reagent solution was prepared and added to increasing concentration of $\mathrm{ON}-\mathrm{Cr}$ extract $(125,250,500$ and $1000 \mu \mathrm{g} / \mathrm{mL}$ ) with subsequent incubation for $30 \mathrm{~min}$. The absorption of reaction mixture was measured spectrophotometrically (UV-3000 O.R.I. Germany) at $517 \mathrm{~nm}$. Ascorbic acid was used as positive control. The percent scavenging activity of samples was calculated using the following equation:

$\%$ scavenging activity $=\frac{\text { absorbance of control-absorbance of plant extract }}{\text { absorbance of control }} \times 100$

The experiment was performed in triplicate. The $\mathrm{IC}_{50}$ values were calculated using GraphPad Prism ${ }^{\odot}$ (version 4.0, Sandiego, CA, USA).

2, 2-Azinobis [3-ethylbenzthiazoline]-6-sulfonic acid (ABTS) free radical scavenging assay For further evaluation of Olax nana antioxidant potentials, ABTS free radical scavenging assay was performed $[41,49]$. The principle of this assay is based on the test sample ability to scavenge 
ABTS free radical cations, ultimately leads to reduced absorbance at $734 \mathrm{~nm}$. After mixing, $\mathrm{K}_{2} \mathrm{~S}_{2} \mathrm{O}_{8}(2.45 \mathrm{mM})$ and ABTS $(7 \mathrm{mM})$, the solution was kept in dark for $12-16 \mathrm{~h}$ to form ABTS free radical cations. A $300 \mu \mathrm{L}$ of $\mathrm{ON}-\mathrm{Cr}$ test sample $(1000 \mu \mathrm{g} / \mathrm{mL}-31.25 \mu \mathrm{g} / \mathrm{mL})$ was gently mixed with ABTS solution $(3.0 \mathrm{~mL})$ in a cuvette. The absorbance of the mixture was measured after every $1 \mathrm{~min}$, for a period of $6 \mathrm{~min}$ continuously on a UV-VIS spectrophotometer (UV-3000 O.R.I. Germany). As a positive control, ascorbic acid was used. The assay was performed in triplicate and calculation of percent inhibition was done using the following equation:

$$
\% \text { scavenging effect }=\frac{\text { control absorbance-sample absorbance }}{\text { control absorbance }} \times 100
$$

The percent inhibition and $\mathrm{EC}_{50}$ value (extract concentration required for $50 \%$ reduction of ABTS radicals) were then calculated for expression of antioxidant potential.

Hydrogen peroxide $\left(\mathrm{H}_{2} \mathrm{O}_{2}\right)$ free radicals scavenging assay As per our previously reported method, the $\mathrm{H}_{2} \mathrm{O}_{2}$ scavenging activity of $\mathrm{ON}-\mathrm{Cr}$ was elucidated [50]. A solution of $\mathrm{H}_{2} \mathrm{O}_{2}(2 \mathrm{mM})$ was prepared in phosphate buffer $(50 \mathrm{mM}, \mathrm{pH} 7.4)$. In a $0.3 \mathrm{~mL}$ of phosphate buffer solution $(50 \mathrm{mM}), 0.1 \mathrm{~mL}$ of test sample was added, which was followed by addition of $0.6 \mathrm{~mL}$ of $\mathrm{H}_{2} \mathrm{O}_{2}$ and then vortexed. The absorbance of solution was measured at $230 \mathrm{~nm}$ after a period of $10 \mathrm{~min}$ (UV-3000 O.R.I. Germany), in comparison to blank. The following equation was used for the calculation of $\mathrm{H}_{2} \mathrm{O}_{2}$ free radical scavenging activity:

$$
\text { Hydrogen peroxide scavenging activity }=\frac{1-\text { sample absorbance }}{\text { absorbance of control }} \times 100
$$

\section{Anticholinesterase assays}

The Ellman's assay was performed to assess the AChE and $\mathrm{BChE}$ enzymes inhibition potentials of $\mathrm{ON}-\mathrm{Cr}$ [51]. The principle of anticholinesterase assay is based on hydrolysis of acetylthiocholine iodide and butyrylthiocholine iodide by respective enzymes, leading to the formation of 5-thio-2-nitrobenzoate anion, which complexes with DTNB to form a yellow color compound, after evaluation by UV-VIS spectrophotometer (UV3000 O.R.I. Germany).

Preparation of solutions Phosphate buffer solution $(0.1 \mathrm{M}$ and $\mathrm{pH}: 8.0)$ was prepared as previously reported [48]. For adjusting the $\mathrm{pH}$, potassium hydroxide was used. The final concentrations of $0.03 \mathrm{U} / \mathrm{mL}$ and $0.01 \mathrm{U} / \mathrm{mL}$ were obtained for AChE (518 U/mg solid) and $\mathrm{BChE}(7-16 \mathrm{U} / \mathrm{mg})$ after respective dilution in the freshly prepared buffer $\mathrm{pH}$ 8.0. Using distilled water, DTNB $(0.0002273 \mathrm{M})$, acetylthiocholine iodide and butyrylthiocholine iodide $(0.0005 \mathrm{M})$ solutions were prepared and stored in a refrigerator $\left(8^{\circ} \mathrm{C}\right)$. The respective dilutions were also prepared for galantamine (positive control) in methanol.

Spectroscopic analysis In a cuvette containing $205 \mu \mathrm{L}$ of $\mathrm{ON}-\mathrm{Cr}$ extract, $5 \mu \mathrm{L}$ of enzyme solution was added, followed by addition of $5 \mu \mathrm{L}$ DTNB reagent. In a water bath, the resulting solution was incubated for $15 \mathrm{~min}$ at $30{ }^{\circ} \mathrm{C}$, with addition of substrate solution $(5 \mu \mathrm{L})$ subsequently. Furthermore, using a UV-VIS spectrophotometer (UV-3000 O.R.I. Germany) the absorbance was calculated at $412 \mathrm{~nm}$. As a standard inhibitor of cholinesterase, $10 \mu \mathrm{g} / \mathrm{mL}$ of galantamine was used as positive control, while the components other than $\mathrm{ON}-\mathrm{Cr}$ extract were considered as negative control. At $30{ }^{\circ} \mathrm{C}$ for $4 \mathrm{~min}$ of reaction time, the absorbance values at specific intervals were noted. The assays were conducted in triplicate, while the change in absorption rate with time gave calculations for the \% enzyme activity and \% enzyme inhibition by galantamine and $\mathrm{ON}-\mathrm{Cr}$ sample.

\section{a- glucosidase inhibitory assay}

The protocol of McCue et al., was adopted for the assessment of ON-Cr $\alpha$-glucosidase inhibitory potential [52]. An enzyme solution was prepared by mixing $120 \mu \mathrm{L}$ of phosphate buffer (0.1 M, pH 6.9) with $\alpha$-glucosidase enzyme $(20 \mu \mathrm{L}$ of $0.5 \mathrm{unit} / \mathrm{mL}$ ). The solution of substrate having $p$ nitrophenyl- $\alpha$ - $D$-glucopyranoside was prepared in phosphate buffer (0.1 M, pH 6.9). The ON-Cr test sample was prepared in a concentration range of $31.25-1000 \mu \mathrm{g} / \mathrm{mL}$ followed by mixing with enzyme solution and incubation for $15 \mathrm{~min}$ at $37^{\circ} \mathrm{C}$. Furthermore, to the mixture of enzyme and test sample, substrate solution $(20 \mu \mathrm{L})$ was added and incubated under the same conditions. The reaction was completed by the addition of sodium carbonate solution $(80 \mu \mathrm{l}$ of $0.2 \mathrm{M}$ ). Using a UV-VIS spectrophotometer (UV3000 O.R.I. Germany), the absorbance of samples was recorded at $405 \mathrm{~nm}$. As a positive control, acarbose was used while the sample devoid of $\alpha$-glucosidase was used as a blank. The experiment was performed in triplicate, while the following equation was used for the calculation of percent inhibition:

$$
\text { \%inhibition }=\frac{\text { control absorbance-sample absorbance }}{\text { control absorbance }} \times 100
$$

The concentration of $\mathrm{ON}-\mathrm{Cr}$ extract which inhibited substrate hydrolysis via $\mathrm{AChE}$ and $\mathrm{BChE}$ enzymes by $50 \%\left(\mathrm{IC}_{50}\right.$ value) was calculated from the dose response curve [53]. The kinetics of enzyme activity was measured in the presence of increasing concentrations of extract. 
Table 1 Different phytochemical tests for aqueous methanolic extract of Olax nana

\begin{tabular}{|c|c|c|c|}
\hline S. No & Phytochemical tests & Observations & Results \\
\hline 1 & Alkaloids & ppt. & + \\
\hline 2 & Flavonoids & $\begin{array}{l}\text { Formation of yellow color which } \\
\text { changed to colorless on acid } \\
\text { addition }\end{array}$ & + \\
\hline 3 & Glycosides & Reddish ppt. is not formed & - \\
\hline 4 & Tannins & Formation of bluish-black color & + \\
\hline 5 & Sterols & green to pink color was absent & + \\
\hline 6 & Saponins & frothing bubbles are formed & + \\
\hline 7 & Anthraquinones & $\begin{array}{l}\text { Red, violet or pink color are not } \\
\text { formed in aqueous layer }\end{array}$ & - \\
\hline 8 & Terpenoids & Appearance of reddish brown color & + \\
\hline
\end{tabular}

\section{Statistical analysis}

All the assays were performed three times, while values were represented as \pm S.E.M. One-way ANOVA followed by Bonferroni's multiple comparison post hoc test was used for the analysis of antioxidant activity and enzyme inhibition assays. At $95 \%$ confidence interval, a $P$ value of $<0.05$ was considered as statistically significant. LineweaverBurk plots $(1 / \mathrm{v}$ versus $1 /[\mathrm{s}])$ where $\mathrm{v}$ is reaction velocity and $[\mathrm{s}]$ is substrate concentration were plotted from assays using a range of plant extract concentrations. The $\mathrm{V}_{\max }$ and $K_{m}$ values were determined using MichaelisMenten kinetics.

\section{Results}

\section{Phytochemical analysis}

The preliminary phytochemical analysis of ON-Cr revealed the presence of various secondary metabolites like alkaloids, flavonoids, tannins, sterols, saponins and terpenoids. Table 1 highlights the observational results of all the phytochemical tests. In the HPLCDAD analysis of ON-Cr, several components were separated in different ratios but gallic acid derivative (25.57\%), hydroxybenzoic acid derivative (17.81) and rutin (5.35\%) were compounds present in higher concentrations as summarized in Fig. 2 and Table 2. The highest concentrated signals were observed at retention times of 6.9, 5.8, $5.2,6.3 \mathrm{~min}$ which were $25.57,17.81,14.41$ and $8.19 \%$ respectively.

\section{Antioxidant assays}

In the DPPH free radical scavenging assay, $\mathrm{ON}-\mathrm{Cr}$ at the concentrations of $31.25,62.50,500$ and $1000 \mu \mathrm{g} / \mathrm{mL}$ demonstrated \% inhibition not significantly different when compared to the positive control (ascorbic acid) $(P>0.05)$ at the same concentration. As shown in Fig. 3, the $\mathrm{IC}_{50}$ value of $\mathrm{ON}-\mathrm{Cr}$ was $71.46 \mu \mathrm{g} / \mathrm{mL}$, while that of ascorbic acid was $31.31 \mu \mathrm{g} / \mathrm{mL}$. Interestingly, in ABTS free radicals scavenging assay, $\mathrm{ON}-\mathrm{Cr}$ only at the concentration of $62.05 \mu \mathrm{g} / \mathrm{mL}$ demonstrated significantly different \% inhibition in comparison to that of ascorbic acid $(P<0.001$ at $95 \%$ confidence interval). While at the concentrations of $31.25,125,250,500$ and $1000 \mu \mathrm{g} / \mathrm{mL}$, the \% inhibition values were not significantly different in comparison to ascorbic acid at similar concentrations $(P>0.05$ at $95 \%$ confidence interval). As shown in Fig. 4 , the $\mathrm{IC}_{50}$ value of ON-Cr was $72.55 \mu \mathrm{g} / \mathrm{mL}$, while that of ascorbic acid (positive control) was $32.37 \mu \mathrm{g} / \mathrm{mL}$. In the $\mathrm{H}_{2} \mathrm{O}_{2}$ anti-radicals assay, $\mathrm{ON}-\mathrm{Cr}$ at the concentrations of $31.25,62.50 \mu \mathrm{g} / \mathrm{mL}$ demonstrated \% inhibition significantly different in comparison to that of ascorbic acid $(P<0.001$ at $95 \%$ confidence interval). While at the concentrations of 125,250 , 500 and $1000 \mu \mathrm{g} / \mathrm{mL}$, the \% inhibition values were not significantly different when compared to ascorbic acid at similar concentrations $(P>0.05$ at $95 \%$ confidence

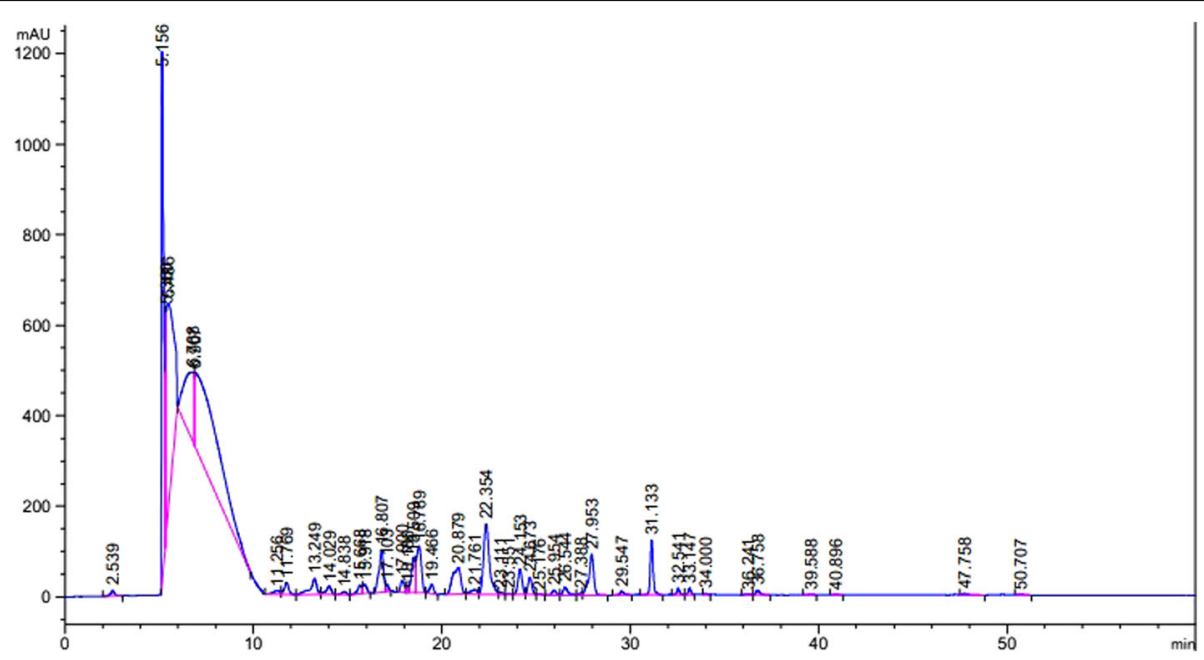

Fig. 2 HPLC-DAD chromatogram of methanolic extract of Olax nana 
Table 2 HPLC-DAD identification of phenolic compounds in Olax nana leaves

\begin{tabular}{|c|c|c|c|c|c|c|}
\hline Peak & $\mathrm{RT}$ (min) & Peak height (mAU) & Peak area \% & Proposed identity of compound* & HPLC-DAD $\lambda \max (\mathrm{nm})$ & References \\
\hline 1 & 2.5 & 13.29053 & 0.320 & Ascorbic Acid & 244 & Mradu et al., 2012 \\
\hline 2 & 5.2 & 1168.32886 & 14.41 & Gallic acid derivative & $273,279,288$ & Aaby et al., 2007 \\
\hline 3 & 5.3 & 504.33762 & 3.19 & Gallic acid derivative & 280 & Mradu et al., 2012 \\
\hline 4 & 5.8 & 456.65558 & 17.81 & Hydroxybenzoic acid derivative & 280 & Santos et al., 2014 \\
\hline 5 & 6.3 & 151.39925 & 8.20 & Hydroxybenzoic acid derivative & 274 & Santos et al., 2014 \\
\hline 6 & 6.9 & 163.31013 & 25.57 & Gallic acid derivative & $271,278,287$ & Aaby et al., 2007 \\
\hline 7 & 11.1 & 8.41879 & 0.33 & Kaempferol-7-O-glucoside & 254 & Ibrahim et al., 2015 \\
\hline 8 & 11.6 & 26.59516 & 0.70 & $p$-Coumaric acid derivative & 313 & Santos et al., 2014 \\
\hline 9 & 13.2 & 35.75774 & 1.36 & Isovitexin-4-O-glucoside & 254 & Ibrahim et al., 2015 \\
\hline 10 & 14.3 & 18.4162 & 0.57 & Caftaric acid & $242 ;$ sh 298; 328 & Carazzone et al., 2013 \\
\hline 11 & 14.9 & 6.63179 & 0.17 & Gallic acid derivative & 280 & Santos et al., 2014 \\
\hline 12 & 15.5 & 19.11495 & 0.46 & Hydroxybenzoic acid derivative & 278 & Santos et al., 2014 \\
\hline 13 & 15.7 & 19.45154 & 0.43 & Hydroxybenzoic acid derivative & 278 & Santos et al., 2014 \\
\hline 14 & 16.9 & 92.68282 & 2.47 & p-Hydroxybenzoic acid & 256 & Santos et al., 2014 \\
\hline 15 & 17.0 & 15.39486 & 0.23 & Caffeoylmalic acid & $327,300,268$ & Santos et al., 2014 \\
\hline 16 & 17.5 & 26.84283 & 0.60 & bis-HHDP-glucose & 232 & Aaby et al., 2007 \\
\hline 17 & 18.1 & 14.13607 & 0.21 & Quercetin-3-O-triglucoside & $268 ; 340$ & Lin et al., 2011 \\
\hline 18 & 18.3 & 77.88322 & 1.70 & Galloyl-HHDP-glucose & 232 & Aaby et al., 2007 \\
\hline 19 & 18.9 & 102.11224 & 2.93 & Apigenin-7-O-rutinoside & 254 & Ibrahim et al., 2015 \\
\hline 20 & 19.9 & 19.88177 & 0.46 & P-coumaric acid derivative & 228,316 & Santos et al., 2014 \\
\hline 21 & 20.7 & 57.97879 & 2.78 & Vanillic acid & $260 ; 292$ & Santos et al., 2014 \\
\hline 22 & 21.4 & 10.30173 & 0.39 & Caffeic acid & $238 ; 298$ sh; 323 & Santos et al., 2014 \\
\hline 23 & 22.3 & 89.48333 & 5.35 & Rutin & 155.3661 & Reference Standard \\
\hline 24 & 23.2 & 4.74129 & 0.10 & Syringic acid & 274 & Santos et al., 2014 \\
\hline 25 & 23.5 & 2.06536 & 0.04 & Proanthocyanidin trimer & 284 & Aaby et al., 2007 \\
\hline 26 & 24.1 & 54.95284 & 1.32 & Quercetin-di-glucoside & $256 ;$ sh 268; 350 & Llorach et al., 2008 \\
\hline 27 & 24.7 & 38.34863 & 0.87 & Quercetine glycoside & $256 ;$ sh 266; 354 & Llorach et al., 2008 \\
\hline 28 & 25.4 & 1.90931 & 0.04 & Quercetine glycoside & $256 ;$ sh 266; 354 & Llorach et al., 2008 \\
\hline 29 & 25.9 & 11.029 & 0.26 & Caffeoylmalic acid & $244 ;$ sh 298; 328 & Llorach et al., 2008 \\
\hline 30 & 26.6 & 17.19059 & 0.49 & p-Coumaric acid & $228 ; 310$ & Santos et al., 2014 \\
\hline 31 & 27.953 & 5.04913 & 0.09 & Pyrogallol & $244 ;$ sh 298; 328 & Reference Standard \\
\hline 32 & 27.7 & 89.48333 & 2.58 & Chicoric acid & $244 ;$ sh 298; 328 & Carazzone et al., 2013 \\
\hline 33 & 29.2 & 8.83803 & 0.22 & Caffeic acid derivative & $242 ;$ sh 298; 322 & Santos et al., 2014 \\
\hline 34 & 31.3 & 120.93526 & 2.08 & Quercetin-3-(caffeoyldiglucoside)- 7-glucoside & $252 ;$ sh 268; 332 & Santos et al., 2014 \\
\hline 35 & 32.7 & 14.63641 & 0.26 & Quercetin-3-d-galactoside & $256 ; 268$ sh; 356 & Santos et al., 2014 \\
\hline 36 & 33 & 14.05107 & 0.24 & Quercetin-3-O-glucoside & $256 ; 268$ sh; 356 & Santos et al., 2014 \\
\hline 37 & 34 & 3.52791 & 0.06 & Rosmarinic acid & $330 ; 290$ sh & Santos et al., 2014 \\
\hline 38 & 36.3 & 2.60122 & 0.08 & Quercetin-3-feruloylsophoroside & $256 ;$ sh 268; 334 & Lin et al., 2011 \\
\hline 39 & 39.6 & 2.02323 & 0.06 & Rosmarinic acid derivative & $290 ; 328$ & Santos et al., 2014 \\
\hline 40 & 40.5 & 2.04721 & 0.04 & cyanidin-3-glucoside & 278sh; 232 & Aaby et al., 2007 \\
\hline
\end{tabular}

*The compounds were identified by comparing absorption spectra of the sample with the standard compounds or from the values reported in the literature

interval). As shown in Fig. 5, the $\mathrm{IC}_{50}$ value of $\mathrm{ON}-\mathrm{Cr}$ was $92.33 \mu \mathrm{g} / \mathrm{mL}$, while that of ascorbic acid was $22.01 \mu \mathrm{g} / \mathrm{mL}$.
Anticholinesterase assays

In the acetylcholinesterase inhibitory activity, the $\mathrm{IC}_{50}$ value for $\mathrm{ON}-\mathrm{Cr}$ was $33.2 \mu \mathrm{g} / \mathrm{mL}$, while that of 


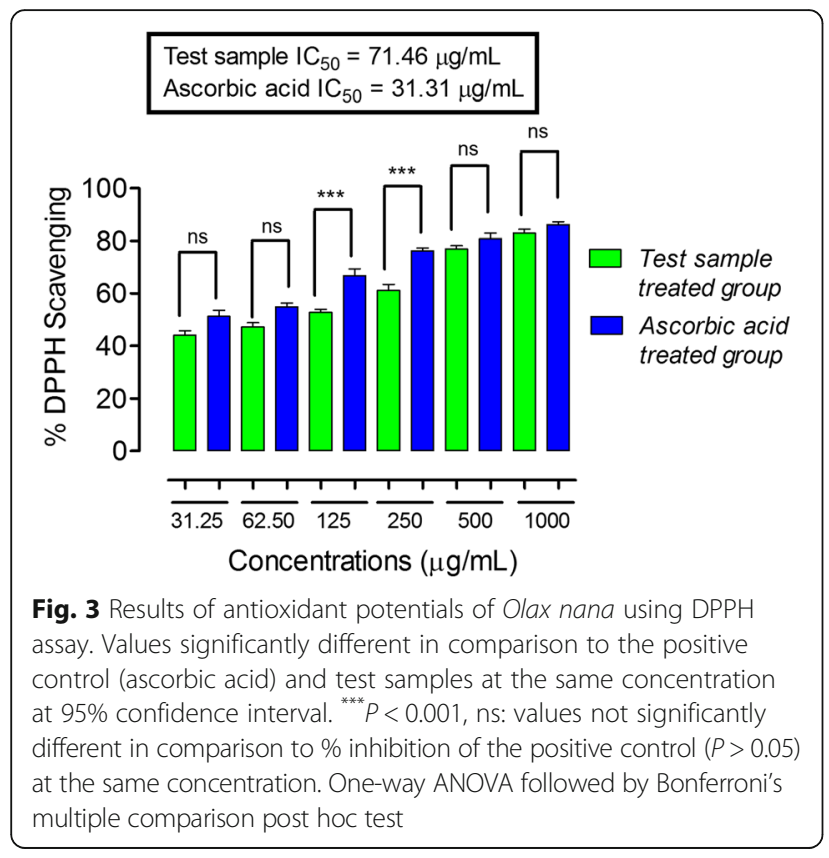

galantamine was $19.26 \mu \mathrm{g} / \mathrm{mL}$ (Fig. 6). Furthermore, in butyrylcholinesterase inhibitory activity, ON-Cr demonstrated potential $\mathrm{IC}_{50}$ value of $55.36 \mu \mathrm{g} / \mathrm{mL}$, while that of galantamine was $24.99 \mu \mathrm{g} / \mathrm{mL}$ (Fig. 7). The strong inhibitory propensity of $\mathrm{ON}-\mathrm{Cr}$ was further corroborated from the Linewear-Burk plots (Fig. 8) in which $\mathrm{ON}-\mathrm{Cr}$ prospectively inhibited the enzymatic activities of both $\mathrm{AChE}$ and $\mathrm{BChE}$, the inhibitory effect was comparable to that of the positive control, galantamine. The $\mathrm{K}_{\mathrm{m}}$ value of the substrates, $\mathrm{ON}-\mathrm{Cr}$ and galantamine for $\mathrm{AChE}$

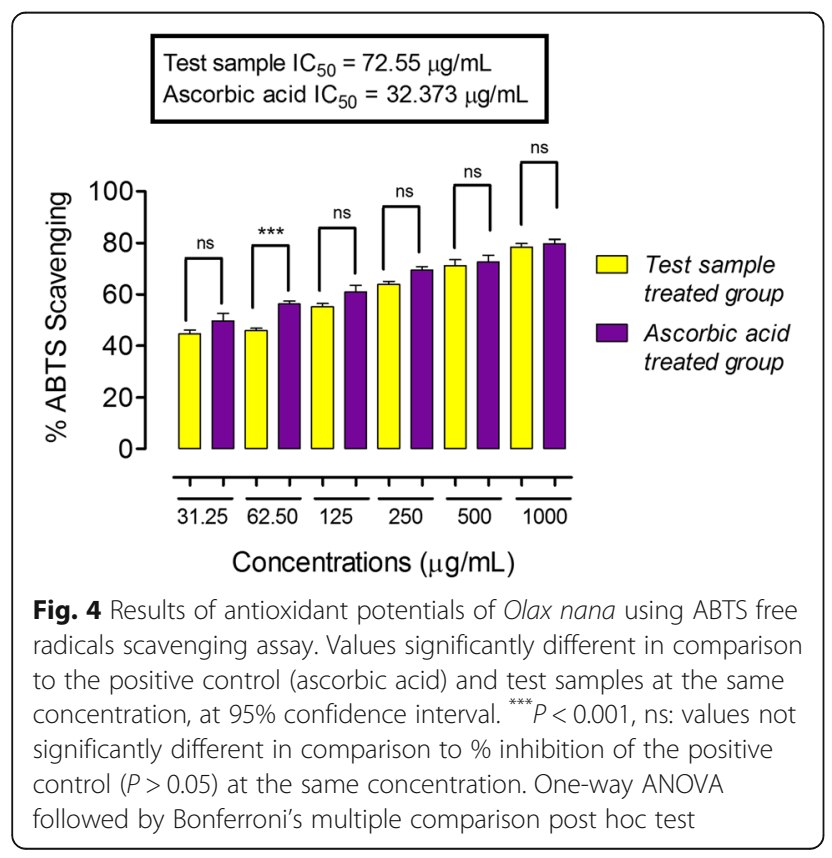

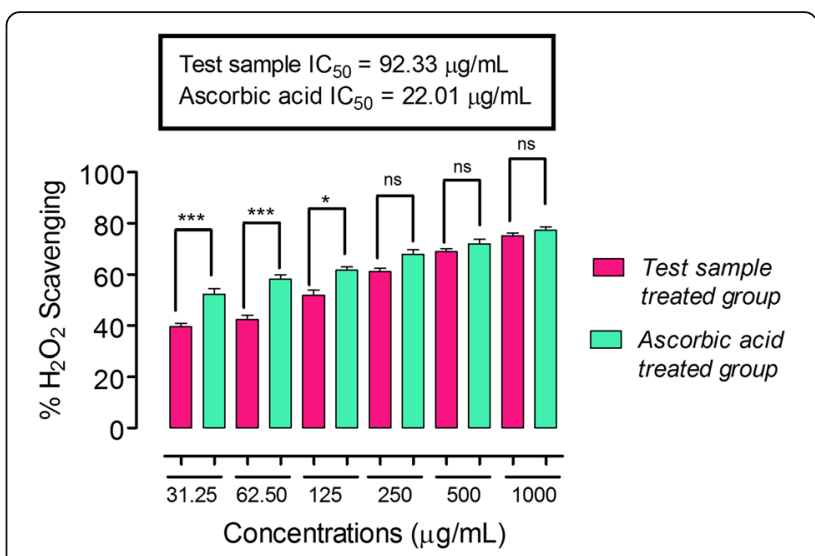

Fig. 5 Results of antioxidant potentials of Olax nana using $\mathrm{H}_{2} \mathrm{O}_{2}$ anti-radicals assay. Values significantly different in comparison to the positive control at the same concentration i.e. ${ }^{* * *} P<0.001,{ }^{* *} P<0.01$, ns: values not significantly different in comparison to $\%$ inhibition of the positive control $(P>0.05)$ at the same concentration. One-way ANOVA followed by Bonferroni's multiple comparison post hoc test

were 20.94 and $16.43 \mu \mathrm{g}$ while the $\mathrm{V}_{\max }$ values were 77 and $79.03 \mu \mathrm{g} / \mathrm{min}$, respectively. Similarly, for $\mathrm{BChE}$, the $\mathrm{K}_{\mathrm{m}}$ values of $\mathrm{ON}-\mathrm{Cr}$ and galantamine were noted as 24.32 and $16.86 \mu \mathrm{g}$, while the $\mathrm{V}_{\max }$ values were calculated as 73.22 and $75.35 \mu \mathrm{g} / \mathrm{min}$, respectively.

\section{a- glucosidase inhibitory assay}

The percent inhibition of $\alpha$-glucosidase via $\mathrm{ON}-\mathrm{Cr}$ was found to be dose-dependent. The $\mathrm{IC}_{50}$ value of $\mathrm{ON}-\mathrm{Cr}$ was $639.89 \mu \mathrm{g} / \mathrm{mL}$, while that of acarbose used as positive control was $61.19 \mu \mathrm{g} / \mathrm{mL}$. The percent inhibition of $\alpha$-glucosidase of $\mathrm{ON}-\mathrm{Cr}$ in a concentration range of $31.25-1000 \mu \mathrm{g} / \mathrm{mL}$ is shown in Table 3. The LinewearBurk plots for the inhibition of $\alpha$-glucosidase by $\mathrm{ON}-\mathrm{Cr}$ and galantamine is shown in Fig. 9. The dissociation constant $\left(\mathrm{K}_{\mathrm{m}}\right)$ and $\mathrm{V}_{\max }$ values of $\mathrm{ON}-\mathrm{Cr}$ for $\alpha$-glucosidase were $31.11 \mu \mathrm{g}$ and $51.01 \mu \mathrm{g} / \mathrm{min}$, respectively, which were comparable to that of positive control, acarbose (30.19 $\mu \mathrm{g}$ and $76.17 \mu \mathrm{g} / \mathrm{min}$ ), thus showing potent inhibitory proclivity against $\alpha$-glucosidase.

\section{Discussion}

In the present study, detailed phytochemical investigation and pharmacogonostic activity of Olax nana aqueous methanolic extract has been reported for the first time. Presence of various secondary metabolites like alkaloids, flavonoids, tannins, sterols, saponins and terpenoids have been found in the preliminary phytochemical analysis. Interestingly, in the HPLC-DAD results the highest concentrated signals were of gallic acid derivatives, hydroxybenzoic acid derivatives and rutin. Previously, Olax scandens has been reported for the presence of various essential phytochemicals like oleanolic acid, octacosanol, aleanolic acid and $\beta$-sitosterol etc. [54]. 

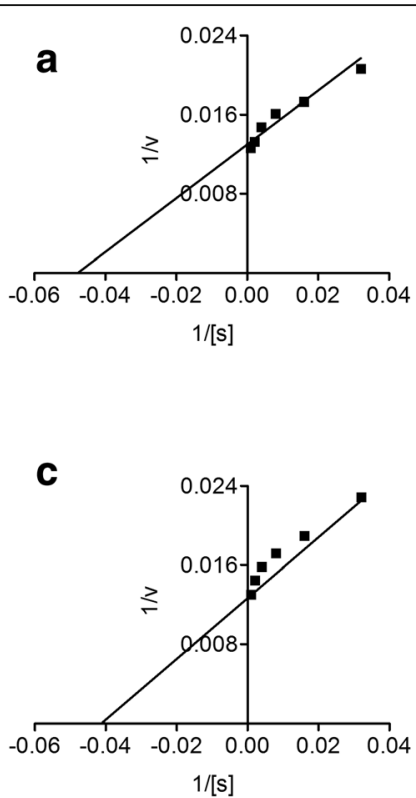
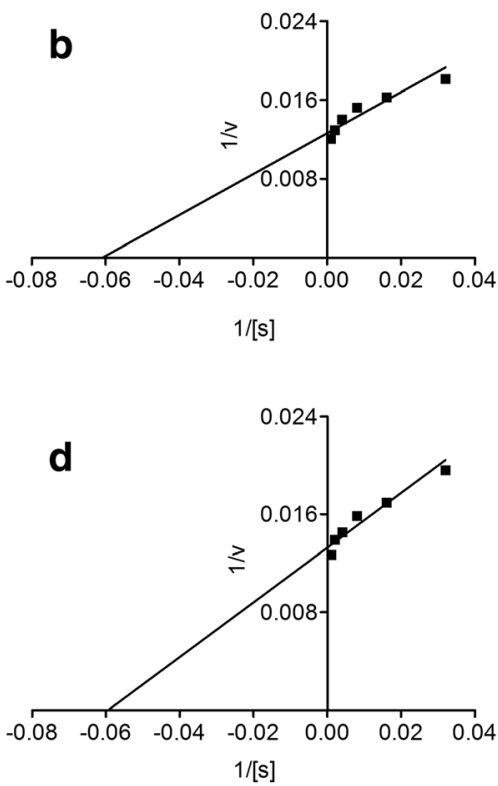

Fig. 6 Lineweaver-Burk plots representing the reciprocal of initial enzyme velocity versus the reciprocal of substrate concentration in the presence of different concentrations of $\mathrm{ON}-\mathrm{Cr}$ and the positive control galantamine for acetylcholinesterase (a and $\mathbf{b})$ and butyrylcholinesterase (c and $\mathbf{d}$ ), respectively

Furthermore, chemical investigation of Olax mannii Oliv also reported to contain useful flavonoid glycoside and derivatives [30].

Free radicals are generated during metabolic processes in the body and are implicated in a variety of disorders including neurodegenerative disorders, coronary heart disease, cancer, diabetes and immune-suppression $[55,56]$. The hydrogen peroxide and singlet oxygen are included in the list of non-free radicals, while nitric oxide, lipid peroxyl,

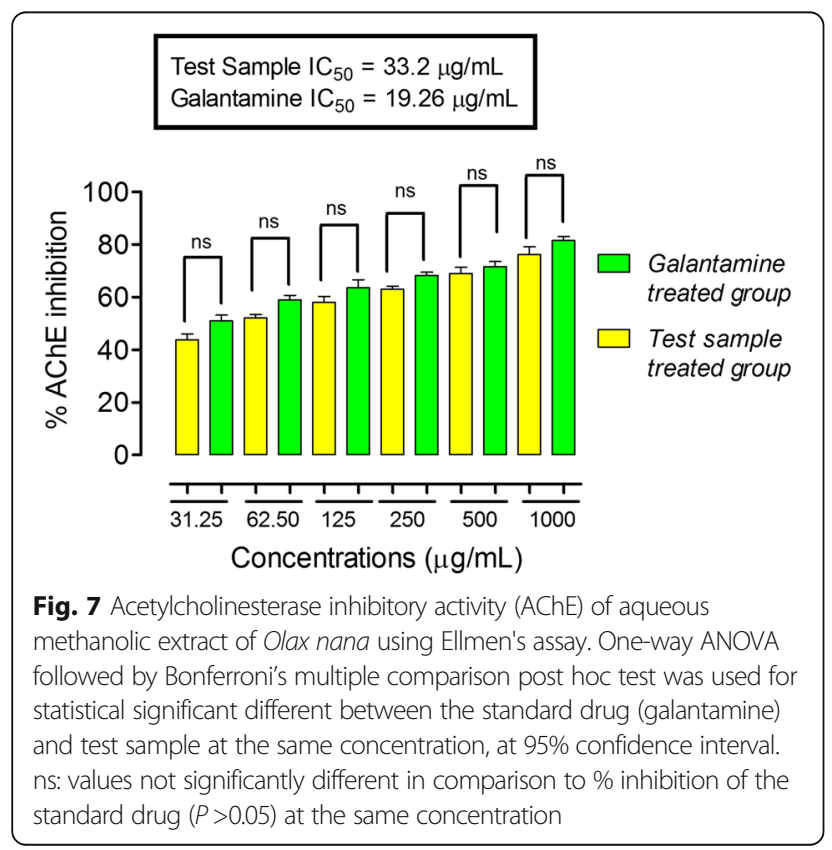

superoxide and hydroxyl are common free radicals [57]. Naturally, the lethal effect of free radicals is nullified in our body via various defense mechanisms, including the protective antioxidant system and chain breaking antioxidants generation [58]. Furthermore, extensive tissue injury occurs when free radical generation rate surpasses the limit of natural scavenging mechanisms. Hence, many diseases including neurogenerative disorders can be cured with the help of drugs having free radical scavenging ability. Plants

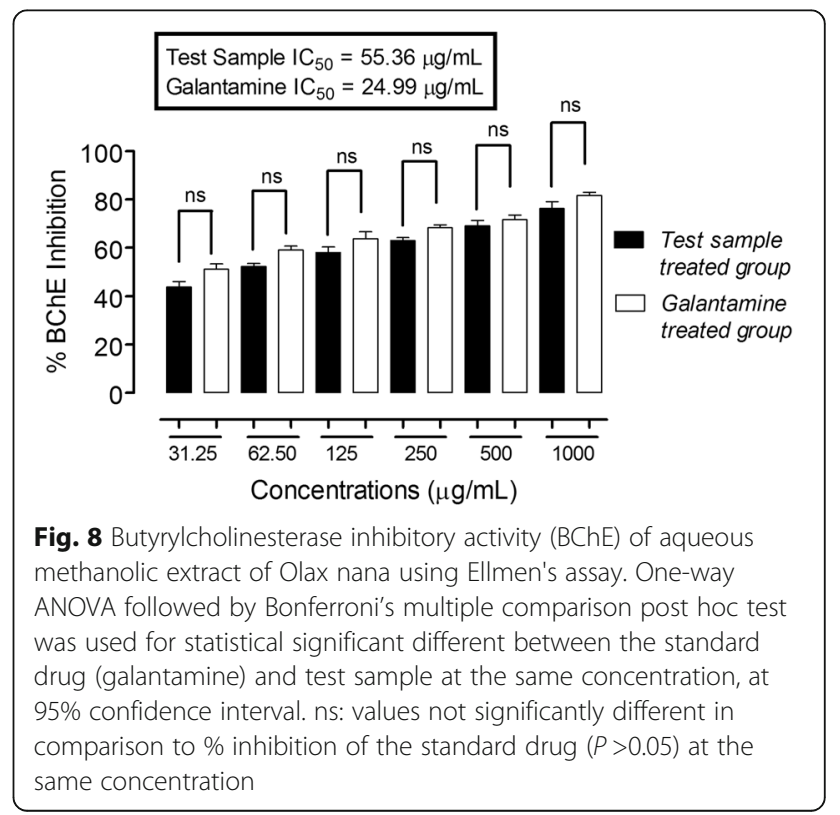


Table 3 a-Glucosidase inhibitory activity of Olax nana

\begin{tabular}{lllll}
\hline $\begin{array}{l}\text { Concentration } \\
(\mu \mathrm{g} / \mathrm{mL})\end{array}$ & $\begin{array}{l}\text { \% inhibition } \\
\text { of extract }\end{array}$ & $\begin{array}{l}\mathrm{IC}_{50} \\
(\mu \mathrm{g} / \mathrm{mL})\end{array}$ & $\begin{array}{l}\text { Acarbose } \\
(\mu \mathrm{g} / \mathrm{mL})\end{array}$ & $\begin{array}{l}\mathrm{IC}_{50} \\
(\mu \mathrm{g} / \mathrm{mL})\end{array}$ \\
\hline 1000 & $55.24 \pm 0.33$ & 639.89 & $77.76 \pm 0.17$ & 61.19 \\
500 & $47.35 \pm 0.49$ & & $73.99 \pm 0.08$ & \\
250 & $41.45 \pm 0.23$ & & $64.97 \pm 0.17$ & \\
125 & $37.18 \pm 0.09$ & & $55.65 \pm 0.43$ & \\
62.5 & $33.08 \pm 0.22$ & & $49.50 \pm 0.45$ & \\
31.25 & $29.79 \pm 1.12$ & & $44.21 \pm 0.26$ & \\
\hline
\end{tabular}

are a valuable resource of antioxidants which have been reported to protect from free radicals induced damage [59]. Significant anti-radical activities was revealed by $\mathrm{ON}-\mathrm{Cr}$ in the DPPH, ABTS and $\mathrm{H}_{2} \mathrm{O}_{2}$ free radical scavenging assays with IC50 values of 71.46, 72.55 and $92.33 \mu \mathrm{g} / \mathrm{mL}$, respectively.
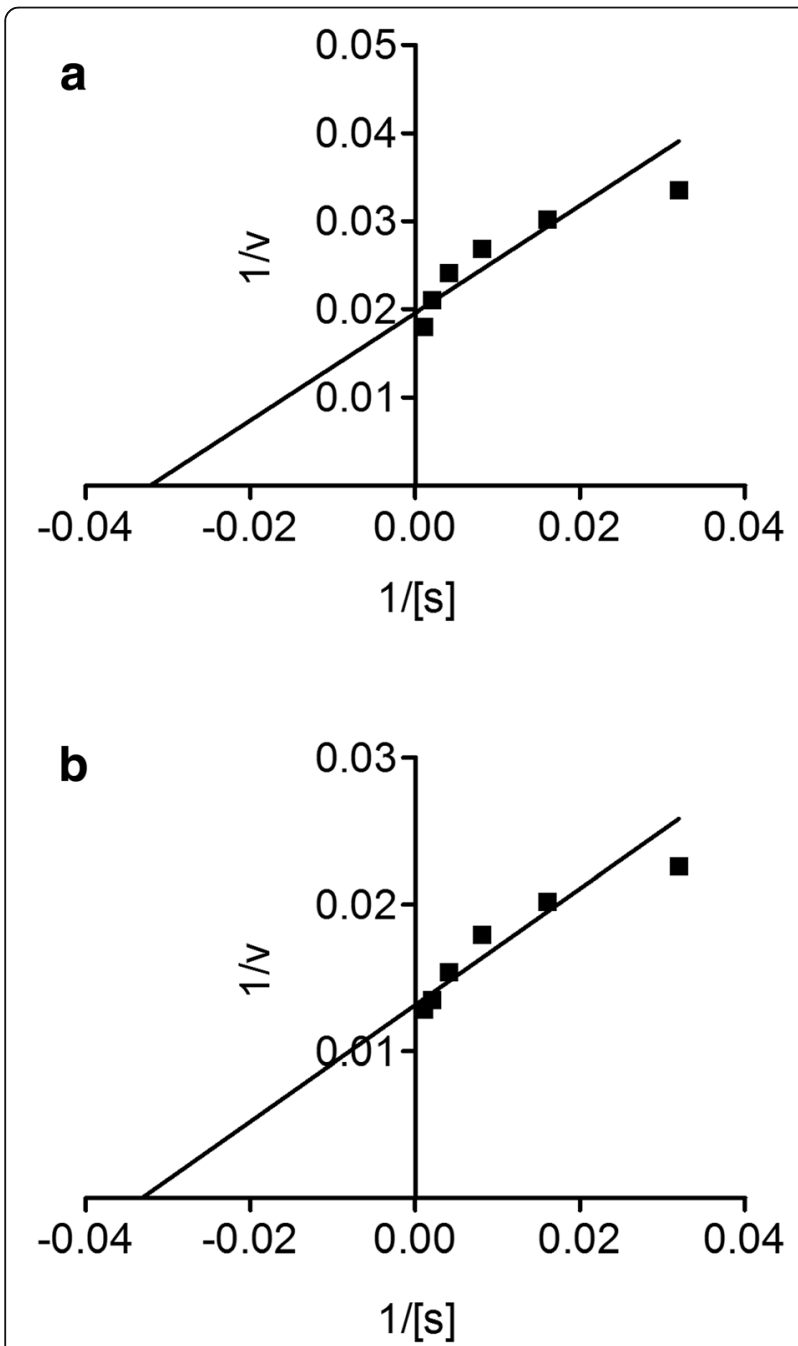

Fig. 9 Lineweaver-Burk plots representing the reciprocal of initial aglucosidase velocity versus the reciprocal of substrate concentration in the presence of different concentrations of $\mathrm{ON}-\mathrm{Cr}(\mathbf{a})$ and the positive control, galantamine (b)
In the treatment of neurological disorders, potential inhibitors of acetylcholinesterase (AChE) and butyrylesterase (BChE) enzymes are of prime importance. These enzymes are involved in the catabolism of acetylcholine (ACh), hence have applications in the treatment of Alzheimer's disease (AD) [60], along with many other neurological disorders [61]. AD is connected with memory impairment, change of behavior and cognitive dysfunction [62]. A decline in the amount of ACh via malfunctioning of various biochemical pathways ultimately leads to $A D$ [63]. AChE along with BChE result in the termination of signal transmission carried out in the synapse via $\mathrm{ACh}$. Hence, by inhibiting these key metabolizing enzymes, we can treat AD and many other neurological disorders [64]. Unfortunately, the available drugs are associated with hepatotoxicity along with many adverse side effects and show effectiveness only in mild type of AD [65]. Hence, it's of prime importance to explore novel remedies for $\mathrm{AD}$, which is effective and have less side effects propensities. Plants are widely explored for potential therapeutic compounds effective in the treatment of neurological disorders [66]. Many research groups including ours have also explored the potential of medicinal plants as valuable source for the treatment of neurodegenerative disorders especially $\mathrm{AD}[35,67]$. In the current study, very potent acetylcholinesterase (AChE) and butyrylesterase (BChE) inhibition potential was demonstrated by $\mathrm{ON}-\mathrm{Cr}$. Interestingly, in both acetylcholinesterase and butyrylcholinesterase inhibitory activities of $\mathrm{ON}-\mathrm{Cr}$, all the concentrations $(31.25,62.50,125,250,500$ and $1000 \mu \mathrm{g} / \mathrm{mL})$ demonstrated \% inhibition values not significantly different in comparison to galantamine (standard drug) at the same concentration $(P>0.05$ at $95 \%$ confidence interval). Previously, Olax Subscorpioidea is also reported to possess neuroprotective, anxiolytic and anti-depressant properties $[18,21]$. Significant results noticed in the antioxidant and anticholinesterase assays of $\mathrm{ON}-\mathrm{Cr}$ may be attributed to the predominant presence of Gallic acid derivatives among the identified compounds (Table 2), which is a common poly phenol and strong antioxidant having promising neuroprotective potentials $[68,69]$. The plant extracts also contain ascorbic acid which is a strong antioxidant. Quercetin and its derivatives are extensively studied as neuroprotective and antioxidant agents [70-72]. ON$\mathrm{Cr}$ contains several quercetin derivatives which may be responsible for the antioxidant and cholinesterase inhibitory potentials of extracts samples. Pyrogallol, another polyphenolic compound was identified via comparison with the standards. This compound is a potent auto-oxidant and stimulates the activation of indigenous antioxidant system [73]. Rutin has a well established antioxidant and neuroprotective potentials [74, 75]. The current antioxidant and anti-cholinesterase potentials of $\mathrm{ON}-\mathrm{Cr}$ can be attributed to the presence of these compounds. Yet further studies 
regarding the isolation and testing of the plant samples will validate its potential use as a neuroprotective agent in folk medicine.

In the early stage of diabetes mellitus type 2 , postprandial hyperglycemia occurs due to impaired secretion of insulin after meal. It is believed that free radicals may cause hyperglycemia and may result in complications, like retinopathy, nephropathy, and memory impairment [76]. The dietary carbohydrates in our meal are digested by a group of enzymes known as glucosidases. Acarbose is one of the key inhibitor of glucosidase, which ultimately downregulate the process of carbohydrate digestion and delays its absorption into the blood. Hence, potential inhibitors of glucosidases can ultimately prevent type 2 diabetes mellitus development via lowering of glucose after meal [77]. Plants have been reported as a great source of these type of inhibitors $[78,79]$. Our results showed interesting inhibition of $\alpha$ glucosidase via $\mathrm{ON}-\mathrm{Cr}$. The dissociation constant $(\mathrm{Km})$ and Vmax values as reported by $\mathrm{ON}-\mathrm{Cr}$ and acarbose were comparable to each other (Fig. 9). To the best of our knowledge, this is the first report of $\alpha$-glucosidase inhibition via any Olax specie.

\section{Conclusions}

This present research is an exclusive report on the phytochemical composition, antioxidant, cholinesterase and $\alpha$-glucosidase inhibitory potentials of Olax nana methanolic extract. The results of enzyme inhibitions and anti-radical activities were highly significant. These results indicate that Olax nana, is highly enriched with potential antioxidant compounds which can be exploited as potential therapy for the treatment of many disorders. In light of the potential biomedical application as demonstrated by the above results, further studies on the bioassay-guided isolation of potential active compounds and their therapeutic evaluation is recommended.

\section{Acknowledgements}

The authors are grateful to the Department of Pharmacy, University of Malakand, Khyber Pakhtoonkhwa, Pakistan, for providing laboratory facilities to conduct experimental work.

\section{Funding}

This research has received no specific grant from any funding agency in the public, commercial, or not for-profit sectors.

\section{Availability of data and materials}

The data presented in this manuscript belong to research work of Muhammad Ovais and has not been deposited in any repository yet. However, the materials are available to the researchers upon request.

\section{Authors' contributions}

$\mathrm{MO}$ and MA carried out experimental work, data collection, evaluation, literature search and wrote the manuscript. ZKS supervised research work, helped in study design and drafted the final version of the manuscript. ATK, SAS, MSJ, AR and MS helped in plant collection, processing data interpretation and statistical analysis. All authors read and approved the final manuscript for publication.
Ethics approval and consent to participate

Not applicable.

\section{Consent for publication}

Not applicable.

Competing interests

The authors declare that they have no competing interest.

\section{Publisher's Note}

Springer Nature remains neutral with regard to jurisdictional claims in published maps and institutional affiliations.

\section{Author details}

'Department of Biotechnology, Quaid-i-Azam University, Islamabad 44000, Pakistan. ${ }^{2}$ Key Laboratory for Biomedical Effects of Nanomaterials and Nanosafety, CAS Center for Excellence in Nanoscience; National Center for Nanoscience and Technology, Beijing 100190, China. ${ }^{3}$ Department of Pharmacy, University of Malakand, Khyber Pakhtunkhwa (KPK), Chakdara 18000, Pakistan. ${ }^{4}$ Department of Eastern Medicine and Surgery, Qarshi University, Lahore, Pakistan. ${ }^{5}$ Department of Plant Sciences, Quaid-i-Azam University, Islamabad 44000, Pakistan. ${ }^{6}$ National Institute for Lasers and Optronics (NILOP), Pakistan Atomic Energy Commission, Islamabad 44000, Pakistan. ${ }^{7}$ Department of Pharmacy, Sarhad University of Science and Information Technology, Peshawar, Pakistan. ${ }^{8}$ Pakistan Academy of Sciences, Islamabad 44000, Pakistan.

Received: 1 June 2017 Accepted: 12 December 2017

Published online: 03 January 2018

\section{References}

1. Khalil AT, Khan I, Ahmad K, Khan YA, Khan J, Shinwari ZK. Antibacterial activity of honey in north-west Pakistan against select human pathogens. J Tradit Chin Med. 2014;34(1):86-9.

2. Khalil AT, Khan I, Ahmad K, Khan YA, Khan M, Khan MJ. Synergistic antibacterial effect of honey and Herba Ocimi Basilici against some bacterial pathogens. J Tradit Chin Med. 2013;33(6):810-4.

3. Ahmad K. Talha Khalil a, Somayya R: antifungal, phytotoxic and hemagglutination activity of methanolic extracts of Ocimum Basilicum. J Tradit Chin Med. 2016; 36(6):794-8.

4. Khalil AT, Ovais M, Ullah I, Ali M, Shinwari ZK, Khamlich S, Maaza M. Sageretia thea (Osbeck.) mediated synthesis of zinc oxide nanoparticles and its biological applications. Nanomedicine (Lond). 2017 Aug;12(15): 1767-89.

5. Khalil AT, Ovais M, Ullah I, Ali M, Shinwari ZK, Maaza M. Physical properties, biological applications and biocompatibility studies on biosynthesized single phase cobalt oxide (Co3O4) nanoparticles via Sageretia Thea (Osbeck). Arab J Chem. 2017. https://doi.org/10.1016/j.arabjc.2017.07.004

6. Khalil AT, Ovais M, Ullah I, Ali M, Shinwari ZK, Hassan D, Maaza M. Sageretia Thea (Osbeck.) modulated biosynthesis of $\mathrm{NiO}$ nanoparticles and their in vitro pharmacognostic, antioxidant and cytotoxic potential. Artif Cells Nanomed Biotechnol. 2017;1-15. https://doi.org/10.1080/21691401.2017. 1345928.

7. Khalil AT, Ovais M, Ullah I, Ali M, Khan Shinwari Z, Maaza M. Biosynthesis of iron oxide (Fe2O3) nanoparticles via aqueous extracts of Sageretia Thea (Osbeck.) and their pharmacognostic properties. Green Chemistry Letters and Reviews. 2017;10(4):186-201.

8. Ovais M, Khalil AT, Raza A, Khan MA, Ahmad I, Islam NU, Saravanan M, Ubaid MF, Ali M, Shinwari ZK. Green synthesis of silver nanoparticles via plant extracts: beginning a new era in cancer theranostics. Nanomedicine. 2016;11(23):3157-77.

9. Ovais M, Raza A, Naz S, Islam NU, Khalil AT, Ali S, Khan MA, Shinwari ZK. Current state and prospects of the phytosynthesized colloidal gold nanoparticles and their applications in cancer theranostics. Appl Microbiol Biotechnol. 2017:101(9):3551-65.

10. World Health Organization. Health of indigenous peoples. Geneva, Switzerland: Factsheets N 326; 2007 [http://www.who.int/mediacentre/ factsheets/fs326/en/].

11. Global Herbal Medicine Market Research Report [https://www.hexaresearch. com/research-report/global-herbal-medicine-market/]. 
12. Global Herbal Supplement Market To Reach $\$ 107$ Billion By 2017 [http:// www.nutraceuticalsworld.com/contents/view_breaking-news/2012-03-07/ global-herbal-supplement-market-to-reach-107-billion-by-2017/].

13. Species in Olax [http://www.theplantlist.org/browse/A/Olacaceae/Olax/].

14. Adeoluwa OA, Aderibigbe AO, Olonode ET. Antinociceptive property of Olax subscorpioidea Oliv (Olacaceae) extract in mice. J Ethnopharmacol. 2014;156:353-7.

15. Odoma S, Zezi AU, Danjuma NM, Ahmed A, Magaji MG. Elucidation of the possible mechanism of analgesic actions of butanol leaf fraction of Olax subscorpioidea Oliv. J Ethnopharmacol. 2017;199:323-7.

16. Saliu JA, Olabiyi AA. Aqueous extract of Securidaca longipendunculata Oliv And Olax subscropioidea inhibits key enzymes (acetylcholinesterase and butyrylcholinesterase) linked with Alzheimer's disease in vitro. Pharm Biol. 2017:55(1):252-7.

17. Popoola TD, Awodele O, Omisanya A, Obi N, Umezinwa C, Fatokun AA. Three indigenous plants used in anti-cancer remedies, Garcinia Kola Heckel (stem bark), Uvaria chamae P. Beauv.(root) and Olax subscorpioidea Oliv. (root) show analgesic and anti-inflammatory activities in animal models. J Ethnopharmacol. 2016;194:440-9.

18. Adeoluwa O, Aderibigbe A, Agu G. Pharmacological evaluation of central nervous system effects of ethanol leaf extract of Olax Subscorpioidea in experimental animals. Drug research. 2016;66(04):203-10.

19. Adegbite OS, Akinsanya YI, Kukoyi AJ, Iyanda-Joel WO, Daniel OO, Adebayo $\mathrm{AH}$. Induction of rat hepatic mitochondrial membrane permeability transition pore opening by leaf extract of Olax subscorpioidea. Pharm Res. 2015;7(Suppl 1):S63.

20. Konan K. N'dah Kouamé Justin BL, Souleymane M, Francis YA: Hepatoprotective and in vivo antioxidant activity of Olax subscorpioidea Oliv.(Olacaceae) and Distemonathus benthamianus Baill.(Caesalpiniaceae). Pharmacogn Mag. 2015;11(41):111.

21. Adeoluwa O, Aderibigbe A, Bakre A. Evaluation of antidepressant-like effect of Olax Subscorpioidea Oliv.(Olacaceae) extract in mice. Drug research. 2015;65(06):306-11.

22. Koné WM, Vargas M, Keiser J. Anthelmintic activity of medicinal plants used in Côte d'Ivoire for treating parasitic diseases. Parasitol Res. 2012;110(6):2351-62.

23. Fankam AG, Kuete V, Voukeng IK, Kuiate JR, Pages J-M. Antibacterial activities of selected Cameroonian spices and their synergistic effects with antibiotics against multidrug-resistant phenotypes. BMC Complement Altern Med. 2011;11(1):104.

24. Balakrishna K, Natarajan R, Purushothaman K: Chemical examination of Olax scandens Roxb. 1983.

25. YH J, Clausen LM, Allred KF, Almada AL, Helferich WG. $\beta$-sitosterol, $\beta$ sitosterol glucoside, and a mixture of $\beta$-sitosterol and $\beta$-sitosterol glucoside modulate the growth of estrogen-responsive breast cancer cells in vitro and in ovariectomized athymic mice. J Nutr. 2004;134(5):1145-51.

26. Awad AB, Chan KC, Downie AC, Fink CS. Peanuts as a source of $\beta$-sitosterol, a sterol with anticancer properties. Nutr Cancer. 2000;36(2):238-41.

27. Thippeswamy G, Sheela M, Salimath BP. Octacosanol isolated from Tinospora cordifolia downregulates VEGF gene expression by inhibiting nuclear translocation of NF-B and its DNA binding activity. Eur J Pharmacol. 2008;588(2):141-50.

28. Napagoda MT, Malkanthi BMAS, Abayawardana SAK, Qader MM, Jayasinghe L. Photoprotective potential in some medicinal plants used to treat skin diseases in Sri Lanka. BMC Complement Altern Med. 2016;16(1):479.

29. Mavundza E, Maharaj R, Finnie J, Kabera G, Van Staden J. An ethnobotanical survey of mosquito repellent plants in uMkhanyakude district, KwaZuluNatal province, South Africa. J Ethnopharmacol. 2011;137(3):1516-20.

30. Okoye FB, Sawadogo WR, Sendker J, Aly AH, Quandt B, Wray V, Hensel A, Esimone CO, Debbab A, Diederich M. Flavonoid glycosides from Olax mannii: structure elucidation and effect on the nuclear factor kappa B pathway. J Ethnopharmacol. 2015;176:27-34.

31. Kumpulainen JT, Salonen JT: Natural antioxidants and anticarcinogens in nutrition, health and disease: Elsevier; 1999.

32. Halliwell B. Free radicals, antioxidants, and human disease: curiosity, cause, or consequence? Lancet. 1994;344(8924):721-4.

33. Barlow SM: Toxicological aspects of antioxidants used as food additives. In: Food antioxidants. Edn.: Springer; 1990: 253-307.

34. Shah SM, Ayaz M, A-u K, Ullah F, Farhan, A-U-HA S, lqbal H, Hussain S. 1, 1 diphenyl, 2-picrylhydrazyl free radical scavenging, bactericidal, fungicidal and leishmanicidal properties of Teucrium stocksianum. Toxicol Ind Health. 2015;31(11):1037-43
35. Ayaz M, Junaid M, Ahmed J, Ullah F, Sadiq A, Ahmad S, Imran M. Phenolic contents, antioxidant and anticholinesterase potentials of crude extract, subsequent fractions and crude saponins from Polygonum Hydropiper L. BMC Complement Altern Med. 2014;14(1):145.

36. Shahidi F, Janitha P, Wanasundara P. Phenolic antioxidants. Critical reviews in food science \& nutrition. 1992;32(1):67-103.

37. Ayaz M, Junaid M, Ullah F, Subhan F, Sadiq A, Ali G, Ovais M, Shahid M, Ahmad A, Wadood A, et al. Anti-Alzheimer's studies on beta-Sitosterol isolated from Polygonum hydropiper L. Front Pharmacol. 2017;8(697)

38. Ayaz M, Junaid M, Ullah F, Sadiq A, Khan MA, Ahmad W, Shah MR, Imran M, Ahmad S. Comparative chemical profiling, cholinesterase inhibitions and anti-radicals properties of essential oils from Polygonum Hydropiper L: a preliminary anti-Alzheimer's study. Lipids Health Dis. 2015;14(1):141.

39. Ayaz M, Sadiq A, Junaid M, Ullah F, Subhan F, Ahmed J. Neuroprotective and anti-aging potentials of essential oils from aromatic and medicinal plants. Front Aging Neurosci. 2017;9:168.

40. Ahmad S, Ullah F, Sadiq A, Ayaz M, Imran M, Ali I, Zeb A, Ullah F, Shah MR. Chemical composition, antioxidant and anticholinesterase potentials of essential oil of Rumex Hastatus D. Don collected from the north west of Pakistan. BMC Complement Altern Med. 2016;16(1):1.

41. Ullah F, Ayaz M, Sadiq A, Hussain A, Ahmad S, Imran M, Zeb A. Phenolic, flavonoid contents, anticholinesterase and antioxidant evaluation of Iris Germanica var; florentina. Nat Prod Res. 2016;30(12):1440-4.

42. van de Laar FA. Alpha-glucosidase inhibitors in the early treatment of type 2 diabetes. Vasc Health Risk Manag. 2008;4(6):1189.

43. Kim Y-M, Jeong $Y-K$, Wang $M-H$, Lee $W-Y$, Rhee $H-I$. Inhibitory effect of pine extract on a-glucosidase activity and postprandial hyperglycemia. Nutrition. 2005;21(6):756-61.

44. Li Y, Wen S, Kota BP, Peng G, Li GQ, Yamahara J, Roufogalis BD. Punica Granatum flower extract, a potent a-glucosidase inhibitor, improves postprandial hyperglycemia in Zucker diabetic fatty rats. J Ethnopharmacol. 2005;99(2):239-44.

45. Ayaz M, Junaid M, Ahmed J, Ullah F, Sadiq A, Ahmad S, Imran M. Phenolic contents, antioxidant and anticholinesterase potentials of crude extract, subsequent fractions and crude saponins from Polygonum hydropiper L. BMC Complement Altern Med. 2014; https://doi.org/10.1186/1472-6882-14-145.

46. Ayaz M, Junaid M, Subhan F, Ullah F, Sadiq A, Ahmad S, Imran M, Kamal Z, Hussain S, Shah S. Heavy metals analysis, phytochemical, phytotoxic 3 and anthelmintic investigations of crude 4 methanolic extract, subsequent fractions and 5 crude saponins from Polygonum Hydropiper L. BMC Complement Altern Med. 2014;14:465.

47. Bengoechea L, Hernández T, Quesada C, Bartolomé B, Estrella I, GómezCordovés C. Structure of hydroxycinnamic acid derivatives established by high-perfomance liquid chromatography with photodiode-array detection. Chromatographia. 1995;41(1-2):94-8.

48. Sadiq A, Mahmood F, Ullah F, Ayaz M, Ahmad S, Haq FU, Khan G, Jan MS, Barresi G, Di Carlo E. Synthesis, anticholinesterase and antioxidant potentials of ketoesters derivatives of succinimides: a possible role in the management of Alzheimerâ $€^{\mathrm{TM}}$ S. Chemistry Central Journal. 2015;9(1):31.

49. Re R, Pellegrini N, Proteggente A, Pannala A, Yang M, Rice-Evans C. Antioxidant activity applying an improved ABTS radical cation decolorization assay. Free Radic Biol Med. 1999;26(9):1231-7.

50. Ruch RJ, S-j C, Klaunig JE. Prevention of cytotoxicity and inhibition of intercellular communication by antioxidant catechins isolated from Chinese green tea. Carcinogenesis. 1989;10(6):1003-8.

51. Ellman GL, Courtney KD, Andres V, Featherstone RM. A new and rapid colorimetric determination of acetylcholinesterase activity. Biochem Pharmacol. 1961;7(2):88IN191-9095.

52. Mccue P, YI KWON, Shetty K. Anti-amylase, anti-glucosidase and antiangiotensin i-converting enzyme potential of selected foods. J Food Biochem. 2005;29(3):278-94.

53. Ayaz M, Junaid M, Ullah F, Sadiq A, Subhan F, Khan MA, Ahmad W, Ali G, Imran M, Ahmad S. Molecularly characterized solvent extracts and saponins from Polygonum hydropiper $\mathrm{L}$ show high anti-angiogenic, anti-tumor, brine shrimp and fibroblast NIH/3T3 cell line cytotoxicity. Front Pharmacol. 2016;7:74.

54. Mukherjee S, Chowdhury D, Kotcherlakota R, Patra S. Potential theranostics application of bio-synthesized silver nanoparticles (4-in-1 system). Theranostics. 2014;4(3):316.

55. Kumar S, Pandey AK: Free radicals: health implications and their mitigation by herbals. 2015.

56. Kumar S, Pandey AK. Chemistry and biological activities of flavonoids: an overview. Sci World J. 2013;2013 
57. Halliwell B, Gutteridge JM: Free radicals in biology and medicine: Oxford university press, USA; 2015.

58. Jacob RA. The integrated antioxidant system. Nutr Res. 1995;15(5):755-66.

59. Kumar S, Mishra A, Pandey AK. Antioxidant mediated protective effect of Parthenium Hysterophorus against oxidative damage using in vitro models. BMC Complement Altern Med. 2013;13(1):120.

60. Nawaz SA, Choudhary MI. New cholinesterase inhibiting bisbenzylisoquinoline alkaloids from Cocculus Pendulus. Chem Pharm Bull. 2004;52(7):802-6.

61. Kandiah N, Pai M-C, Senanarong V, Looi I, Ampil E, Park KW, Karanam AK, Christopher S. Rivastigmine: the advantages of dual inhibition of acetylcholinesterase and butyrylcholinesterase and its role in subcortical vascular dementia and Parkinson's disease dementia. Clin Interv Aging. 2017;12:697.

62. Rathore S, Habes M, Iftikhar MA, Shacklett A, Davatzikos C. A review on neuroimaging-based classification studies and associated feature extraction methods for Alzheimer's disease and its prodromal stages. Neurolmage. 2017;

63. Callahan PM, Bertrand D, Bertrand S, Plagenhoef MR, Terry AV. Tropisetron sensitizes a7 containing nicotinic receptors to low levels of acetylcholine in vitro and improves memory-related task performance in young and aged animals. Neuropharmacology. 2017;117:422-33.

64. Xiao S, Wang T, Ma X, Qin Y, Li X, Zhao Z, Liu X, Wang X, Xie H, Jiang Q. Efficacy and safety of a novel acetylcholinesterase inhibitor octohydroaminoacridine in mild-to-moderate Alzheimer's disease: a phase I multicenter randomised controlled trial. Age Ageing. 2017;1

65. McEneny-King A, Osman W, Edginton AN, Rao PP. Cytochrome P450 binding studies of novel tacrine derivatives: predicting the risk of hepatotoxicity. Bioorg Med Chem Lett. 2017;

66. Wightman EL. Potential benefits of phytochemicals against Alzheimer's disease. Proc Nutr Soc. 2017:1-7.

67. Ahmad S, Ullah F, Sadiq A, Ayaz M, Imran M, Ali I, Zeb A, Ullah F, Shah MR Chemical composition, antioxidant and anticholinesterase potentials of essential oil of Rumex Hastatus D. Don collected from the north west of Pakistan. BMC Complement Altern Med. 2016;16:29.

68. Yilmaz Y, Toledo RT. Major flavonoids in grape seeds and skins: antioxidant capacity of catechin, epicatechin, and gallic acid. J Agric Food Chem. 2004;52(2):255-60.

69. Lu Z, Nie G, Belton PS, Tang H, Zhao B. Structure-activity relationship analysis of antioxidant ability and neuroprotective effect of gallic acid derivatives. Neurochem Int. 2006;48(4):263-74.

70. Zbarsky V, Datla KP, Parkar S, Rai DK, Aruoma OI, Dexter DT. Neuroprotective properties of the natural phenolic antioxidants curcumin and naringenin but not quercetin and fisetin in a 6-OHDA model of Parkinson's disease. Free Radic Res. 2005;39(10):1119-25.

71. Ossola B, Kääriäinen TM, Männistö PT. The multiple faces of quercetin in neuroprotection. Expert Opin Drug Saf. 2009;8(4):397-409.

72. Dok-Go H, Lee KH, Kim HJ, Lee EH, Lee J, Song YS, Lee Y-H, Jin C, Lee YS, Cho J. Neuroprotective effects of antioxidative flavonoids, quercetin,(+ )-dihydroquercetin and quercetin 3-methyl ether, isolated from Opuntia Ficus-Indica Var. saboten. Brain Res. 2003;965(1):130-6.

73. Shao J, Wu Z, Yu G, Peng X, Li R. Allelopathic mechanism of pyrogallol to Microcystis Aeruginosa PCC7806 (cyanobacteria): from views of gene expression and antioxidant system. Chemosphere. 2009;75(7):924-8.

74. Yang J, Guo J, Yuan J. In vitro antioxidant properties of rutin. LWT-Food Science and Technology. 2008;41(6):1060-6.

75. Tongjaroenbuangam W, Ruksee N, Chantiratikul P, Pakdeenarong N, Kongbuntad W, Govitrapong P. Neuroprotective effects of quercetin, rutin and okra (Abelmoschus Esculentus Linn.) in dexamethasone-treated mice. Neurochem Int. 2011;59(5):677-85.

76. Maritim A. Sanders a, Watkins rJ: diabetes, oxidative stress, and antioxidants: a review. J Biochem Mol Toxicol. 2003;17(1):24-38.

77. Liu L, Deseo MA, Morris C, Winter KM, Leach DN. Investigation of aglucosidase inhibitory activity of wheat bran and germ. Food Chem. 2011;126(2):553-61.

78. Fu G, Li W, Huang X, Zhang R, Tian K, Hou S, Li Y. Antioxidant and alphaglucosidase inhibitory activities of isoflavonoids from the rhizomes of Ficus tikoua bur. Nat Prod Res. 2017:1-7.

79. Zhao J-Q, Wang Y-M, Yang Y-L, Zeng Y, Mei L-J, Shi Y-P, Tao Y-D. Antioxidants and a-glucosidase inhibitors from "Liucha"(young leaves and shoots of Sibiraea laevigata). Food Chem. 2017;230:117-24.

\section{Submit your next manuscript to BioMed Central and we will help you at every step:}

- We accept pre-submission inquiries

- Our selector tool helps you to find the most relevant journal

- We provide round the clock customer support

- Convenient online submission

- Thorough peer review

- Inclusion in PubMed and all major indexing services

- Maximum visibility for your research

Submit your manuscript at www.biomedcentral.com/submit
Biomed Central 